Int. J. Dev. Biol. 54: 231-236 (2010)

doi: $10.1387 / \mathrm{ijdb} .082837 \mathrm{kt}$

\title{
Contemporary comparative placenta research - an interview with Allen Enders
}

\author{
KENT L. THORNBURG*,1 and JOAN S. HUNT² \\ ${ }^{1}$ Heart Research Center, Portland, Oregon, USA and \\ ${ }^{2}$ Department of Anatomy \& Cell Biology, University of Kansas Medical Center, Kansas City, Kansas, USA
}

\begin{abstract}
This Special Issue of The International Journal of Developmental Biology is dedicated to Allen C. Enders. His accomplishments are being honored because of his outstanding scientific contributions to our understanding of the development and mature structure of the mammalian placenta. He has consistently focused his research efforts on cutting edge questions related to the interaction of maternal and fetal tissues. While he has officially retired, he continues to study implantation and comparative placentology at the ultrastructural level. Enders has served as a link between the early placentologists who struggled to resolve the thinnest of layers in the placenta using light microscopy and modern day placentologists who now take advantage of confocal microscopy and electron microscopy to elucidate pathways for nutritive molecules as they pass from maternal to fetal compartments. Enders' ground breaking electron micrographs will stand the test of time in revealing the relationships between embryonic tissue and maternal structures as they are variously modified in different species. The symbiotic interactions of genetically distinct tissues that form the placenta are required to nourish the fetus and perpetuate the species. This mysterious process makes mammalian reproduction the most exciting field of research in all of biology. The story of Allen Enders' success will be an inspiration to all up and coming placentologists who are destined to discover the exciting world of placental biology.
\end{abstract}

KEY WORDS: placenta, Allen Enders, comparative placentation, trophoblast, yolk sac

Allen Enders stands in the chief rank among placental researchers. His published work on comparative placental structure and implantation spans five decades, encompasses multiple species and provides the framework upon which functional studies on the placenta rest today. Allen Enders is a product of the midwestern United States, having been born in Wooster, Ohio. He grew up in an academic family. His father, Robert K. Enders, was a professor of biology at Swarthmore College with a special interest in zoogeography and mammalian reproduction including delayed implantation. Robert Enders chaired the Department of Biology from 1946 until 1970 when he retired. Robert Enders received a fellowship to study at the Carnegie Institute from 1930 to 1932. While there, he met placentologist, George B. Wislocki from Baltimore. Wislocki solidified collaborations across the Atlantic with Emmanuel C. Amoroso, a stellar placentologist whose remarkable career brought kudos to the Royal Veterinary College where he served as Chair of Veterinary Physiology. The senior Enders took advantage of the opportunities to work on the cutting edge of reproduction biology with international experts. While at the Carnegie Institute, Robert was encouraged to work on fur animals because there was some grant funding available at that time for such studies. This led him to study mink and fur seal reproduction. Robert's acquaintances such as Wislocki, Amoroso, Carl Hartman and G.W. Corner were naturally passed on to his son, Allen.

Allen Enders was educated in Zoology at Swarthmore College where he received a Bachelor of Arts degree in biology. Later, he was awarded a master's and a doctoral degree (1952, 1955, respectively) at Harvard University. Early in his career, Allen demonstrated a gift for teaching as illustrated by his appointment as a Teaching Fellow during his graduate training years. He also showed an early talent for research. He moved to the Rice Institute in Houston, Texas, as a Research Associate in 1954. Thereafter, Allen moved steadily upwards through academic positions at Rice after which time he moved to Washington University in St. Louis, Missouri, where he gained associate and full professorships in the Department of Anatomy. In his final academic move, Allen was recruited in 1976 to the University of

\footnotetext{
*Address correspondence to: Kent L. Thornburg. Heart Research Center, 3181 SW Sam Jackson Park Road, Portland, Oregon 97239, USA. Tel: +1-503 4942382 (Office). Fax+1-503-494-6969. e-mail: thornbur@ohsu.edu
} 


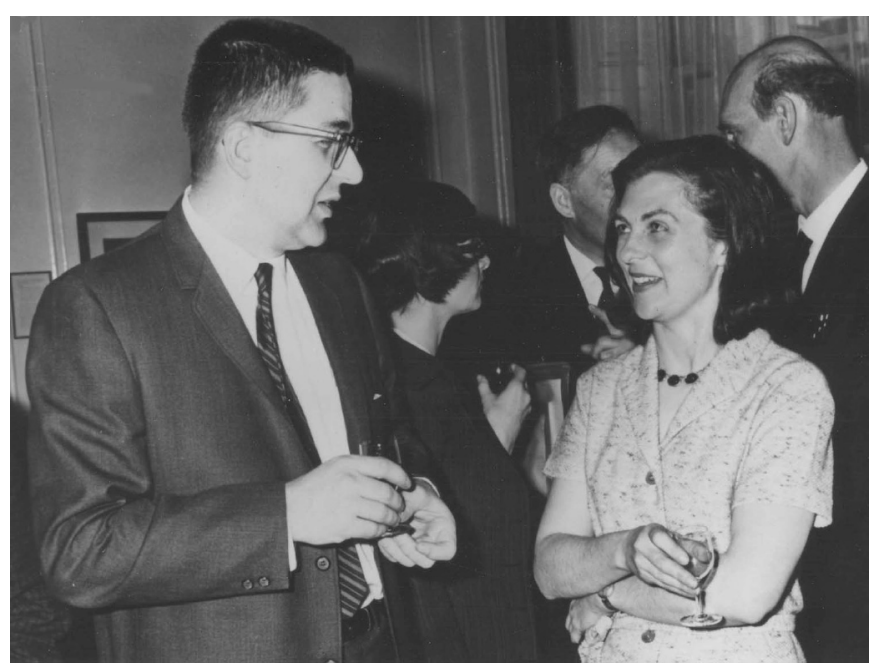

Fig. 1. Allen Enders with Anne McLaren at a Ciba Symposium on "Fine Structure of the Blastocyst: Some Comparative Studies" held in London, U.K. (1965).

California in Davis to take the chair of Human Anatomy, a position which he held for a decade. Allen remains Professor Emeritus of the renamed Department of Cell Biology and Human Anatomy at the University of California - Davis.

The armadillo became an important study animal for Allen Enders early in his career. This interesting mammal which bears identical quadruplets with a hemomonochorial placenta (like the human), became the subject of nearly a dozen of Allen's papers. He began to study the armadillo as a graduate student when Dr. Wislocki bought him one. The newly purchased armadillo turned out to be pregnant and a perfect animal from which to start a career.

The intersection of the lives of Allen Enders and Dixon Boyd (the latter is featured in an accompanying article in this issue by his sons, Robert and Richard Boyd; see Boyd and Boyd, 2010) demonstrates the importance of scientific exchange in the study of the placenta across the Atlantic over the last half century. Boyd and Amoroso visited Washington University in St. Louis during the time when Edward Dempsy was the Chair of the Department of Obstetrics and Gynecology. During that visit they had ample time to exchange their latest findings on placenta and embryo development. When Allen visited Dixon in Cambridge, they discussed the accumulation of glycogen in the uterus and placenta. Allen remembers that Dixon had a large photograph of a human placenta in utero in situ above his desk.

Allen Enders became a leading thinker in the world of placental biology at an early point in his career. He worked with outstanding leaders in the field. These included William Wimsatt and Harland Mossman (the latter trained Howard Hillemann, the thesis advisor for one of us (KLT)). In their 1972 textbook, Human Embryology, Dixon Boyd and Mossman joined forces (along with honorary author, the late W. J. Hamilton) in highlighting Allen Ender's work. Their wonderful book with its modernized color figures contained a concise chapter on comparative placentation. In this section, Boyd and Mossman wrote:

"Before the advent of the study of ultrathin sections by the electron microscope, it was believed that thinning of the placental barrier proceeded to a "hemo-endothelial"con- dition in the rabbit and certain rodents. It is now known, after adequate sampling by electron microscopy (Enders, 1965), that extremely thin layers of trophoblast do persist in the rabbit, rat, mouse, hamster and guinea pig. It is remarkable that the thickness of the entire separation membrane in these forms is often in the range of 0.5 micron, which is very close to the resolving power of the light microscope... Recent co-operative electron microscope studies of the shrewplacentaby Enders, Mossman and Wimsatt...indicate that a thin spongy layer of trophoblast does intervene between the two endothelia."

In 1973, Enders, along with Wimsatt and Mossman published the data referred to above and settled the controversy that arose concerning the persistence of trophoblast as a component of the interhemal barrier in the shrew (Wimsatt et al., 1973). Thus, the hemo-endothelial placenta has never been proven to exist. Allen's habit of tackling the most controversial issues led to his work being highly read and appreciated. One must have spent time in his laboratory to fully recognize that his attention to detail in processing and photographing tissue was and is the secret to his success. His care for detail was applied to tissue fixation, sectioning, staining and light and electron photomicroscopy.

Throughout his career, Allen Enders has been an outstanding scientist with tremendous leadership gifts. To name just two of his awards, in his undergraduate years he was named Claude C. Smith Scholar and in his tenure at Washington University he served as the Henry Elliot Research Professor of Anatomy. He has been President of both the Perinatal Research Society and the American Association of Anatomists. In recent years he has accepted the Pioneer in Reproduction Research Award given by the Frontiers in Reproduction training course at the Marine Biology Laboratories, Woods Hole, Massachusetts, and the $\mathrm{Na}$ tional Institutes of Health (NIH) Senior Lecturer Award by the International Federation of Placenta Associations.

Allen Enders has contributed generously to the growth and development of placenta research, serving on the editorial boards of eight scientific journals and committing to $\mathrm{NIH}$ research grant review panels for nine years. Most recently, he chaired the Steering Committee for the National Cooperative Program on

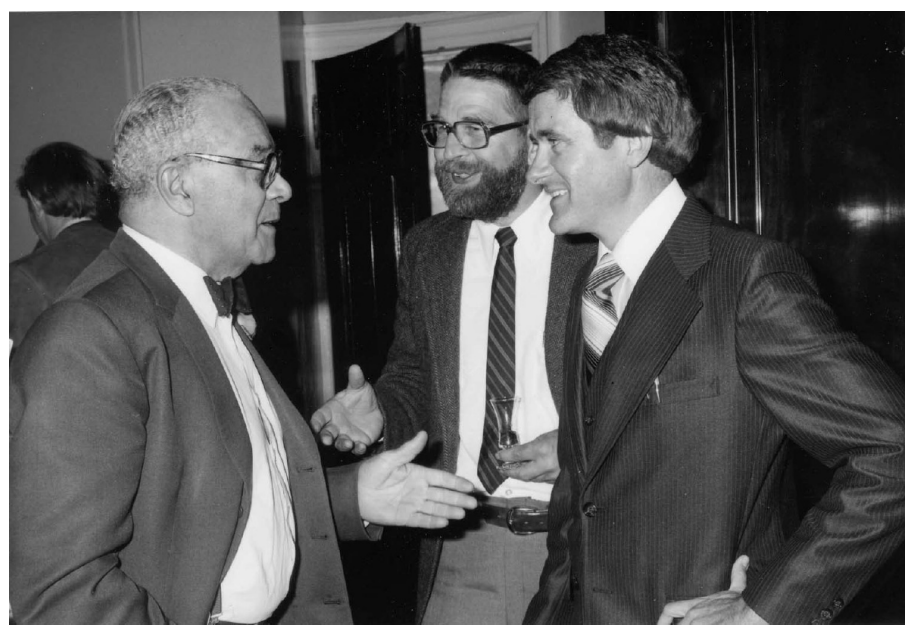

Fig. 2. Allen Enders (center) with Professors Emmanuel C. Amoroso (left) and Allen Beer (right), at a Ciba Symposium (1976). 
Trophoblast-Maternal Tissue Interactions. Allen has an enviable record of more than thirty years of continuous support from the $\mathrm{NIH}$ for his research program (1963-1999), and has produced more than 200 scientific reports as well as two books. A highly popular lecturer, he has given more than 80 invited presentations at scientific meetings across the world.

Allen Enders is alive and well at his home in Davis, California. $\mathrm{He}$ and his wife, Sandy, continue to work as a great research team. Allen is serving as his own technician, cutting his own gold and silver thin sections for electron microscopy. He maintains his warm enthusiasm for all things placental, including the big black holes in the field that need enlightenment. The reader will note that he has continued to publish throughout his post-retirement years with two papers recently published in 2008 .

As editors, we are pleased and highly honored to offer this glimpse of Allen Ender's signal contributions to the field of placentology.

In this article, aspects of Allen's life and career related to his productivity and stature in the world of placenta research are presented in a question and answer format so that his thoughts on specific issues are not diluted by unnecessary commentary.

\section{How did you become interested in comparative placenta- tion?}

I was taken on several field trips by my father as a youngster, and participated in a study of the mountain viscacha [a type of rodent] in Peru the summer before entering college. I had a general interest in mammalian reproduction, reinforced by Frederick Hisaw's (Hisaw discovered the hormone relaxin) courses in endocrinology and endocrine techniques in graduate school. While studying the reproductive tract of the mink for my Ph.D. thesis, I noted that the diagrams of the endotheliochorial placenta seen in common embryology textbooks did not closely resemble the hypertrophied endothelium and thick interstitial membrane around the maternal capillaries in the placental labyrinth of the mink. (The mink reproductive tracts were obtained in Pennsylvania, so I incubated specimens to demonstrate succinic dehydrogenase by placing the vials in my axilla as I drove back to

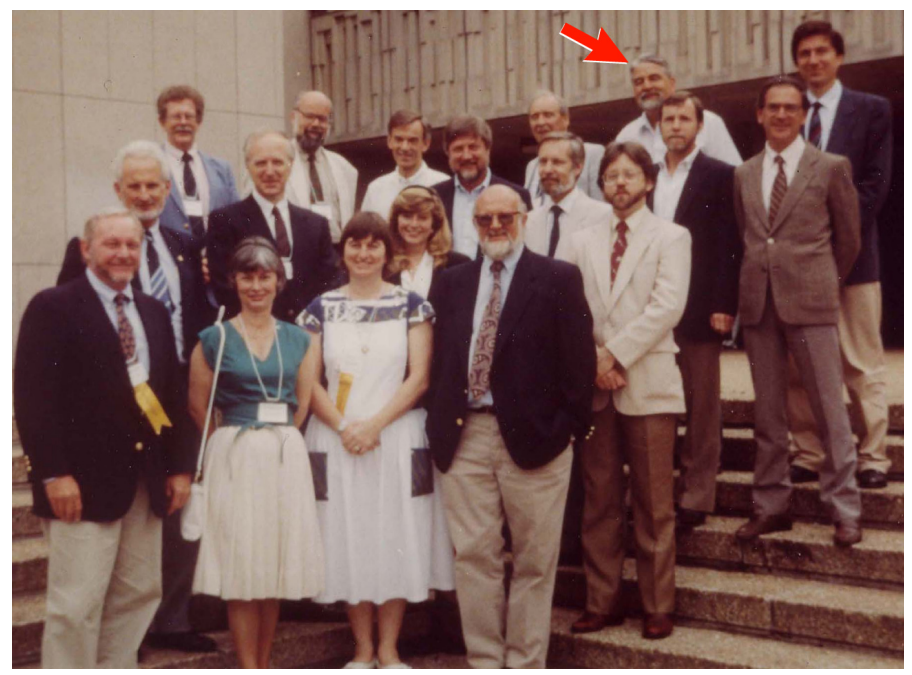

Fig. 3. Allen Enders (arrow) with participants at a symposium on the Placenta, Toronto, Canada (1993).

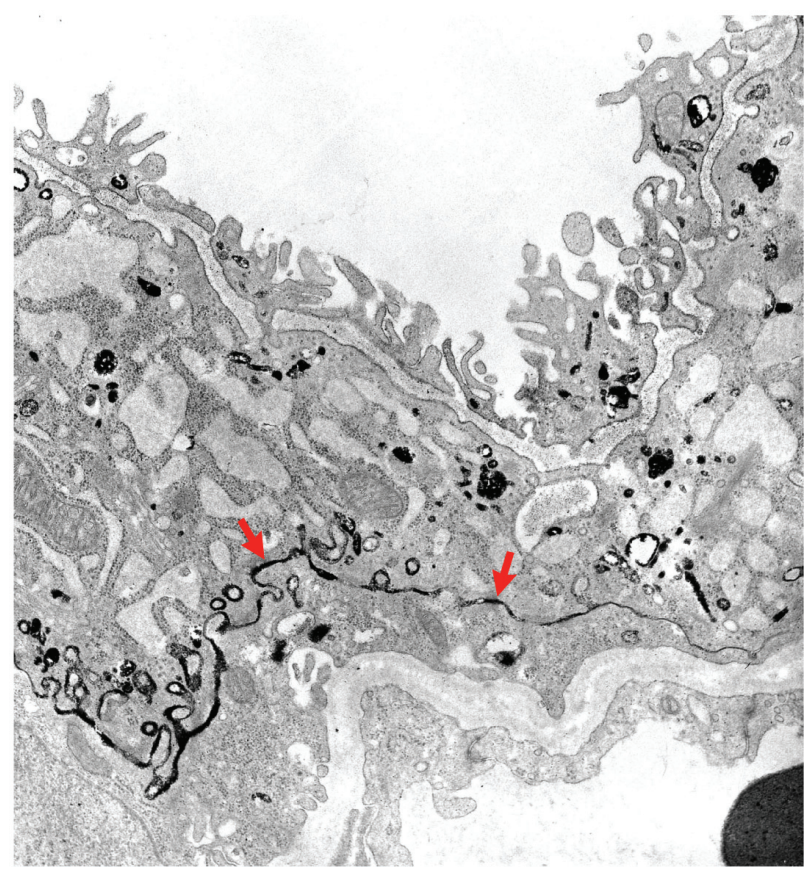

Fig. 4. Transmission electron microscopy facilitates identification of placental transport of a tracer protein through the placenta of the little brown bat. Note the accumulation between the two layers of trophoblast (arrows).

Massachusetts. This method was not published!)

I went to Rice Institute in Houston to study reproduction in the armadillo. In trying to determine what controlled the delay of implantation, Dale Buchanan and I ovariectomized pregnant armadillos during delay, expecting to develop a regimen of progesterone and estrogen to allow implantation. Surprisingly, ovariectomy itself resulted in implantation approximately 18 days after deletion of the ovaries. This meant I could study implantation more readily than the mechanism by which it was delayed. The very interesting way in which the yolk sac and villous hemochorial placenta of the armadillo develop led me to compare it with placentation in other species.

Among the unexpected benefits of placentology were occasions for professional interactions with innovative investigators from many nations, including Anne McLaren (University of Cambridge) at a Ciba Symposium held in London in 1965 (Fig. 1) [for a recent tribute to Anne McLaren, see DeFelici, 2009; see also "In Memoriam of Anne McLaren" by Renfree and Short (2008); Clarke, 2001; Warnock, 2001, Papaioannou, 2001 and an interview with Anne McLaren by Brigid Hogan, Hogan, 2001)] and Professors Amoroso and Beer at a second Ciba Symposium in 1976 (Fig. 2). Figure 3 is a group of scientists participating in a symposium on the placenta held in Toronto in 1983.

\section{What were the cutting edge issues when you began your research career?}

The immunological tolerance of the conceptus was certainly one of the questions, including whether or not there was a physical barrier between maternal and fetal structures at the junctional zone. Another interesting question was whether or not there were any placentas in which the fetal endothelium was 


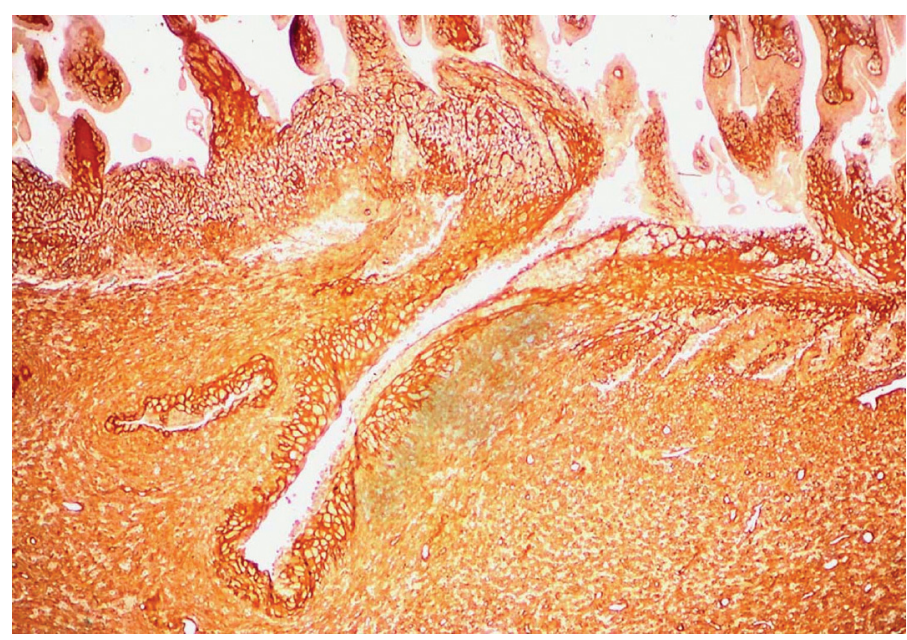

Fig. 5. Immunohistochemistry was a new tool that in this figure is used to identify entry of a maternal artery into the intervillous space. The extracellular matrix secreted by cytotrophoblast is stained for Type IV collagen (dark pink), which surrounds the cytotrophoblast cells lining the artery as well as those in the trophoblastic shell. Primate maternalfetal junction: macaque placenta, 40 days gestation.

directly exposed to maternal endothelium, as had been suggested by Mossman for the shrew, rat and mouse (Mossman \& Owers, 1963). In endocrinology, many investigators were trying to determine what co-enzymes might be controlled by hormones; the idea of hormone receptors and hormonal control of transcription were both still years away.

\section{How has changing technology altered your approach to research?}

Transmission electron microscopy (Fig. 4) enabled a much more precise examination of the different layers interposed between maternal and fetal vasculature. It also showed evidence of cellular activities such as pinocytosis and phagocytosis, etc. Immunohistochemistry has helped not only in identification of cells but by localizing substances involved in the physiological activity of placental layers. It has enabled much better approaches to understanding the ways in which trophoblast can facilitate placental exchanges.

Coons, Leduc and Kaplan introduced immunohistochemistry in 1951 (Coons et al., 1951), but it was not until the hybridoma method for producing (monoclonal) antibodies and better methods for isolating proteins were developed that the method really took off. Figure 5 shows that it was possible to identify a component of the extracellular matrix secreted by cytotrophoblast, Type IV collagen, using this method, and could identify the cytotrophoblast cells themselves using anti-cytokeratin (Fig. 6).

\section{What are your three most interesting findings and what led you to study these?}

I have always been intrigued with the way in which implantation and placentation occurs in different species. Admittedly my interest is rather abstract and not necessarily focused on particular problems. In the course of studying these aspects, I think the observation that syncytial trophoblast penetrates the uterine epithelium by infiltrating between and around epithelial cells and sharing adhesion junctions with these cells in higher primates and many other mammals has changed our idea of how invasion begins.

The observation, with Barry King (Enders \& King, 1988), that the earliest extraembryonic mesoderm in higher primates is derived from the hypoblast (primary endododerm) rather than either the primitive streak or trophoblast, demonstrated that some of this layer has a different origin than that of the intraembryonic mesoderm. This observation also had an interesting clinical relevance (Bianchi et al., 1993). Studies with Barry King and Tom Blankenship on the remodeling of the walls of maternal arteries by the invasion of intraluminal cytotrophoblast and the subsequent formation of shell-like extracellular matrix by these cells in the tunica media of the arteries has demonstrated that this is the major method of vessel remodeling in the decidua basalis of macaque and baboon placentas (Blankenship et al., 1993a, 1993b), as illustrated in Figures 7 and 8.

Both the divergence in structure and commonality of factors in
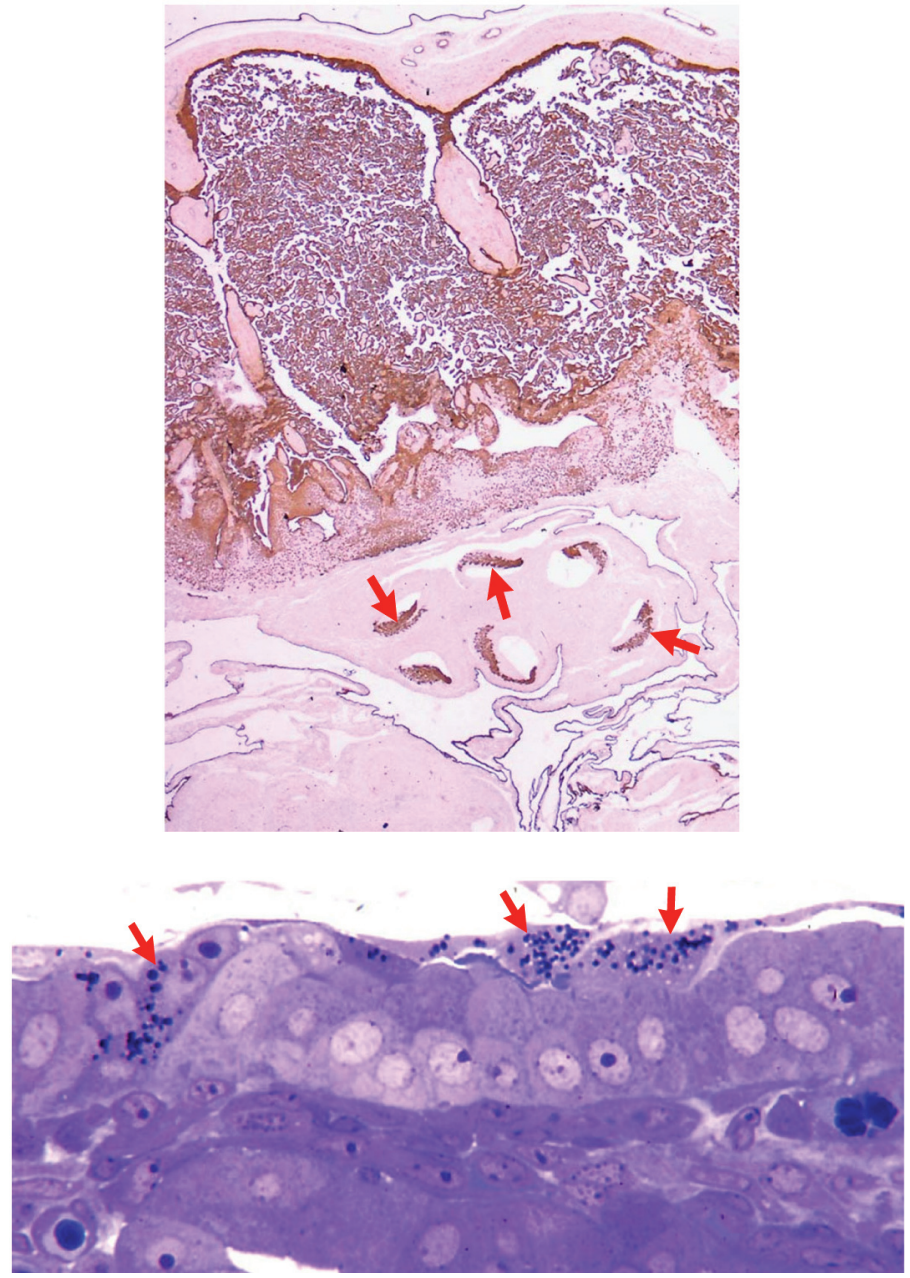

Fig. 6 (Top). Coils of a uterine artery infiltrated with cytotrophoblast cells which are immunostained for cytokeratin (arrows). Macaque placenta, 128 days gestation.

Fig. 7 (Bottom). A toluidine blue stain reveals masses of syncytial trophoblast with contained lipid (arrows) invading the uterine epithelium in the Western spotted skunk at implantation. 


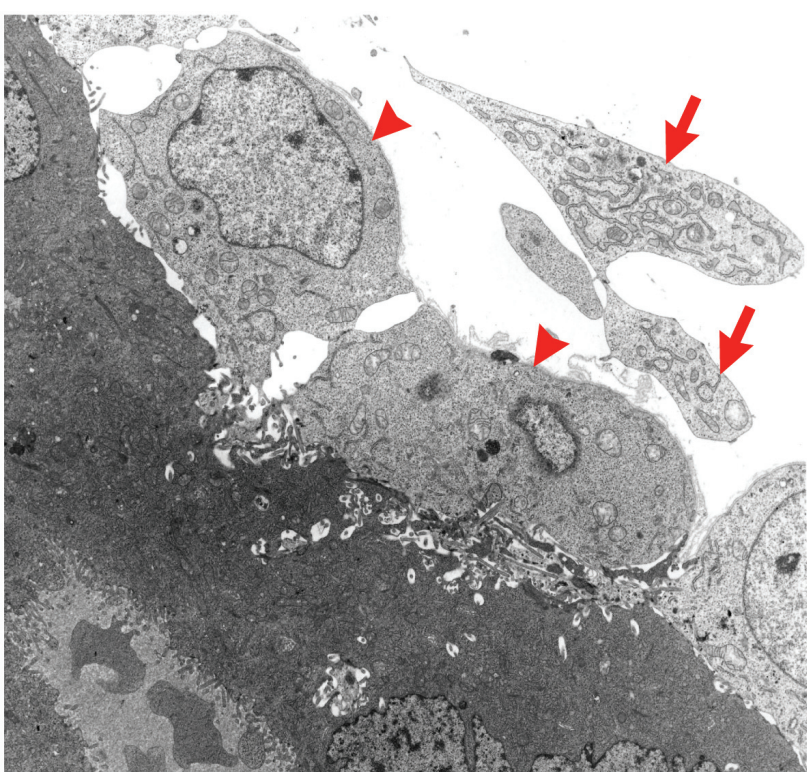

Fig. 8. Mesenchymal cell derivation. Mesenchymal cells (arrows) detached from the endoderm of the primary yolk sac are situated above cytotrophoblast cells (arrowheads) in the placenta of the macaque.

placentation are highlighted by comparative studies. For example, there can be reduced diffusion distance between maternal and fetal bloods, despite the presence of multiple layers. Different structures are used differently; for example the yolk sac may be principally a structure for blood formation in some species, but a significant region for protein transfer even in late pregnancy in other species. One can find similar fetal-maternal interactions at different stages of placental development in highly unrelated species. The multiple forms that trophoblast takes at different times and in different species demonstrates the developmental resilience of this first-formed tissue type. Finally, the importance of well-fixed and embedded specimens in order to obtain the most information from morphological material has certainly been highlighted by these comparative studies.

\section{What scientific controversies have been addressed by your work?}

With Mike Nelson, we demonstrated that the projections from the uterine epithelium of the rat were structures for ingesting fluids, i.e. pinopods, rather than secretory structures, which was one of the suggestions at the time (Enders \& Nelson, 1973). With Sandy and Rick Welsh, we showed several ways in which the endometrium facilitates implantation in the rat, including penetration of the basal lamina of the uterine luminal epithelium by processes from decidual cells (Schlafke et al., 1985).

Several of our studies have indicated that initial invasion in implantation in different species is an invasive process rather than an erosive process. It also appears that it is syncytial trophoblast rather than cytotrophoblast that is the initial invader of the uterine epithelium and syncytial trophoblast is also the first type of trophoblast to broach maternal capillaries in higher primates.

\section{What light has study of normal structure shed on our under- standing human placental pathology?}

Like most pure biologists, I have probably paid less attention to pathology than I should have. For example, in looking at placentas from polytoccous species we tend to select the normal placentas, ignoring the unusually small ones, thus missing a chance to possibly gain insights on placental insufficiency. Various of the comparative studies, including our in vitro studies with macaque blastocysts showing that trophoblast readily penetrates epithelial sheets from non-reproductive organs (Enders et al., 1995), indicate that in higher primates implantation is probably negatively controlled by the uterus.

It is true of the vast majority of animals that correction, i.e. decrease, in number of young occurs relatively early in gestation. In the plains viscacha, with its super-abundance of blastocysts, only those near the caudal end of the uterus, with presumed better uterine vasculature, develop (Weir, 1971). Some exceptions to this early correction are the American antelope where the more caudal conceptus in a uterine horn tends to rupture the more cranial one (O'Gara, 1969). The horse also is an exception where twins may lead to death of both conceptuses; although one might think that this is because the conceptus normally occupies both horns and the body of the uterus; we have found some damage between two conceptuses as early as day 22 (Enders and Liu, 1991; Enders and Liu, 2000; Enders et al., 2002).

\section{What portion of the world's placentas have been described?}

That is a tough question. It would be very small-probably fewer than one percent of the species but the data are better at the order and family levels. Nevertheless, there are probably novel placental arrangements that are as yet undiscovered. In addition, the evolutionary relationships among placentas are understudied. Arrangements like those found among hyenas and bats do not yet fit clearly into any evolutionary scheme. There is an

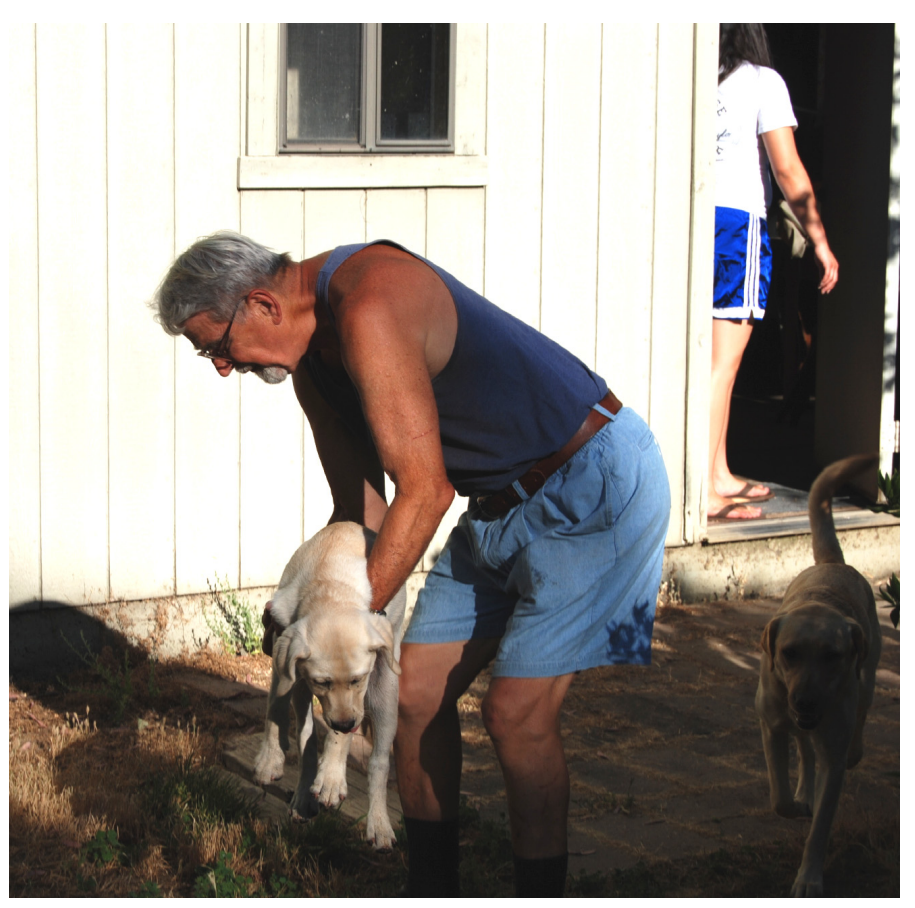

Fig. 9. Allen Enders at home (2007). We are pleased to tell our junior colleagues that even great scientists like Allen Enders have their warm side, as shown here where Allen is giving care to a puppy. 
enormous need for more research in comparative placentology and evolution.

\section{What work remains in the area of comparative placentation?}

There has been very little work on structure function relationships among placentas of various types. Three issues come to mind. 1) What is the role of oxygen, or anaerobiasis, in the early stages of placentation? 2) What are the comparative features of blastocyst-uterine epithelium relationships? 3) To what extent are choriovitelline and chorioallantoic placentas important across species? It is disappointing that many outstanding comparative placentologists have not continued their work because of a lack of funding for this kind of research. Grant applicants these days are more prone to use faddish techniques because they appeal to reviewers.

\section{What work remains in the area of implantation?}

Except for adhesion molecules, there has been little work on the cellular adaptations of trophectoblast and uterine epithelium in preparation for implantation. The ferret is a good animal to study in this regard and it is disappointing that it has been little studied. The invasion process needs more attention. There are several mechanisms that underlie the invasion process. For example, horses and cows have different approaches to developing intimate relationship between mother and fetus. In addition, there is the issue of timing. What are the mechanisms that simultaneously prepare the blastocyst and the uterine epithelium for successful implantation. This is especially interesting in animals that have delayed implantation but it has important implications for human reproduction as well.

\section{Among the papers that you have published, what are your favorites?}

Those following are the ones with which I am most pleased:

ENDERS, A.C. (1965). Fine structure of trophoblast in several hemochorial placentas. Am. J. Anat. 116:29-68. [This paper clarified trophoblast layering in several species, and introduced the terminology hemomonochorial, -dichorial and -trichorial]

SCHLAFKE, S. and ENDERS, A.C. (1975). Cellular basis of interaction between trophoblast and uterus at implantation. Biol. Reprod. 12:41-67. [This publication illustrated the types of initial epithelial penetration that takes place in several species]

The next three papers show how trophoblast invades the endometrium during the lacuna state of placenta formation.

ENDERS, A.C. (1995). Transition from lacunar to villus stage of implantation in the macaque, including establishment of the trophoblastic shell. Acta. Anat. 152: 151-169.

ENDERS, A.C., LANTZ, K.C. and SCHLAFKE, S. (1996). Preference of invasive cytotrophoblast for maternal vessels in early implantation in the macaque. Acta. Anat. 155: 145-162.

ENDERS, A.C. and BLANKENSHIP, T.N. (1997). Modification of endometrial arteries during invasion by cytotrophoblast cells in the pregnant macaque. Acta. Anat. 159: 169-193.

In a recent paper, I discuss rates of invasion of trophoblast into endometrial arteries:

ENDERS A.C. (2007). Implantation in the macaque: expansion of the implantation site during the first week of implantation. Placenta 28: 794. [In this paper, rates of invasion of trophoblast into endometrial arteries were discussed].

\section{References}

BLANKENSHIP, T.N., ENDERS, A.C. and KING, B.F. (1993a). Trophoblastic invasion and the development of uteroplacental arteries in the macaque: immunohistochemical localization of cytokeratins, desmin, type IV collagen, laminin, and fibronectin. Cell Tissue Res. 272: 227-236.

BLANKENSHIP, T.N., ENDERS, A.C. and KING, B.F. (1993b). Trophoblastic invasion and modification of uterine veins during placental development in macaques. Cell Tissue Res. 274: 135-144.

BIANCHI, D.W., WILKINS-HAUG, L.E., ENDERS, A.C. and HAY, E.D. (1993). Origin of extraembryonic mesoderm in experimental animals: relevance to chorionic mosaicism in humans. Am. J. Med. Genet. 46: 542-550.

BOYD, R. and BOYD, R. (2010). Sir Joseph Barcroft, Cambridge placental and fetal research (1933-1966) and inter-generational Science. Int. J. Dev. Biol. 54: 257 268 (doi: 10.1387/ijdb.082762rb).

CLARKE, A.G. (2001). Anne McLaren-a tribute from her research students. Int. J. Dev. Biol. 45: 491-495.

COONS, A.H., LUDUC, E.H. and KAPLAN, M.H. (1951). Localization of antigen in tissue cells: VI. The fate of injected foreign proteins in the mouse. J. Exp. Med. 93: $173-188$

DE FELICI, M. (2009). Primordial germ cell biology at the beginning of the $X X$ Century. Int. J. Dev. Biol. 53: 891-894.

ENDERS, A.C., DOUGLAS, G.C., MEYERS, S. and VANDEVOORT, C.A. (2005). Interactions of macaque blastocysts with epithelial cells in vitro. Human Reprod. 20: 3026-3032.

ENDERS, A.C. and KING, B.F. (1988). Formation and differentiation of extraembry onic mesoderm in the rhesus monkey. Am. J. Anat. 181: 327-340.

ENDERS, A.C. and LIU, I.K.M. (1991). Lodgement of the equine blastocyst in the uterus from fixation through endometrial cup development. J. Reprod. Fertil. Suppl. 44: 427-438.

ENDERS, A.C. and LIU, I.K.M. (2000). A unique exocelom-like space during early pregnancy in the horse. Placenta 21: 575-583.

ENDERS, A.C., LIU, I.K.M. and MCCARTHY, C.J. (2002) Equine Development. http://medocs.ucdavis.edu/cha/embryo.

ENDERS, A.C. and NELSON, D.M. (1973). Pinocytotic activity of the uterus of the rat. Am. J. Anat. 138: 277-299.

HOGAN, B. (2001). From embryo to ethics: a career in science and social responsibility. An interview with Anne McLaren. Int. J. Dev. Biol. 45: 477-482.

MOSSMAN, H.W. and OWERS, N. (1963). The shrew placenta: Evidence that it endothelio-endothelial in type. Am. J. Anat. 113: 245-271.

O'GARA, B.W. (1969). Unique aspects of reproduction in the female pronghorn (Antilocapra americana). Am. J. Anat. 125: 217-232.

PAPAIOANNOU, V.E. (2001). The McLaren effect-a personal view. Int. J. Dev. Biol. 45: $483-486$

RENFREE, M. and SHORT, R. (2008). In memoriam of Anne McLaren. Int. J. Dev. Biol. 52: 1-2

SCHLAFKE, S., WELSH, O. and ENDERS, A.C. (1985). Penetration of the basa lamina of the uterine luminal epithelium during implantation in the rat. Anat. Rec. 212: 47-56.

WARNOCK, M. (2001). Anne McLaren as teacher. Int. J. Dev. Biol. 45: 487-490.

WEIR, B.J. (1971). The reproductive organs of the female plains viscacha, Lagostomus maximus. J. Reprod. Fertil. 25: 365-373.

WIMSATT, W.A., ENDERS, A.C. and MOSSMAN, H.W. (1973). A reexamination of the chorioallantoic placental membrane of a shrew, Blarina brevicauda: resolution of a controversy. Am. J. Anat. 138: 207-233. 


\section{Further Related Reading, published previously in the Int. J. Dev. Biol.}

See our recent Special Issue Epigenetics \& Development edited by Saadi Khochbin and Stefan Nonchev at:

http://www.ijdb.ehu.es/web/contents.php?vol=53\&issue=2-3

See Special Issue Pattern Formation edited by Michael K. Richardson and Cheng-Ming Chuong at:

http://www.ijdb.ehu.es/web/contents.php?vol=53\&issue =5-6

Spatiotemporal expression of the selenoprotein $\mathbf{P}$ genein postimplantational mouse embryos

Se-Ra Lee, Jung-Min Yon, In-Jeoung Baek, Mi-Ra Kim, Chun-Gui Park, Beom-Jun Lee, Young-Won Yun and Sang-Yoon Nam

Int. J. Dev. Biol. (2008) 52: 1005-1011

Puzzles of mammalian fertilization - and beyond

J. Michael Bedford

Int. J. Dev. Biol. (2008) 52: 415-426

An activating mutation in the PDGF receptor-beta causes abnormal morphology in the mouse placenta

Camilla Looman, Tong Sun, Yang Yu, Agata Zieba, Aive Ahgren, Ricardo Feinstein, Henrik Forsberg, Carina Hellberg, Carl-Henrik Heldin, Xiao-Qun Zhang, Karin Forsberg-Nilsson, Nelson Khoo, Reinald Fundele and Rainer Heuchel

Int. J. Dev. Biol. (2007) 51: 361-370

A simple in vivo approach to investigate invasive trophoblast cells Juan A. Arroyo, Toshihiro Konno, Darya C. Khalili and Michael J. Soares Int. J. Dev. Biol. (2005) 49: 977-980

Control of reproduction by Polycomb Group complexes in animals and plants Anne-Elisabeth Guitton and Frederic Berger

Int. J. Dev. Biol. (2005) 49: 707-716

Commitment of hematopoietic stem cells in avian and mammalian embryos: an ongoing story

Françoise Dieterlen-Lièvre

Int. J. Dev. Biol. (2005) 49: 125-130

Changes in the placenta and in the rat embryo caused by the demethylating agent 5azacytidine.

M Vlahovic, F Bulic-Jakus, G Juric-Lekic, A Fucic, S Maric and D Serman

Int. J. Dev. Biol. (1999) 43: 843-846

Transgenic mice ubiquitously expressing human placental alkaline phosphatase (PLAP): an additional reporter gene for use in tandem with beta-galactosidase (lacZ). M J Skynner, D J Drage, W L Dean, S Turner, D J Watt and N D Allen Int. J. Dev. Biol. (1999) 43: 85-90

Involvement of the proto-oncogene c-ets 1 and the urokinase plasminogen activator during mouse implantation and placentation.

D Grevin, J H Chen, M B Raes, D Stehelin, B Vandenbunder and X Desbiens Int. J. Dev. Biol. (1993) 37: 519-529

The human placenta becomes haemochorial at the 13th week of pregnancy. J M Foidart, J Hustin, M Dubois and J P Schaaps

Int. J. Dev. Biol. (1992) 36: 451-453
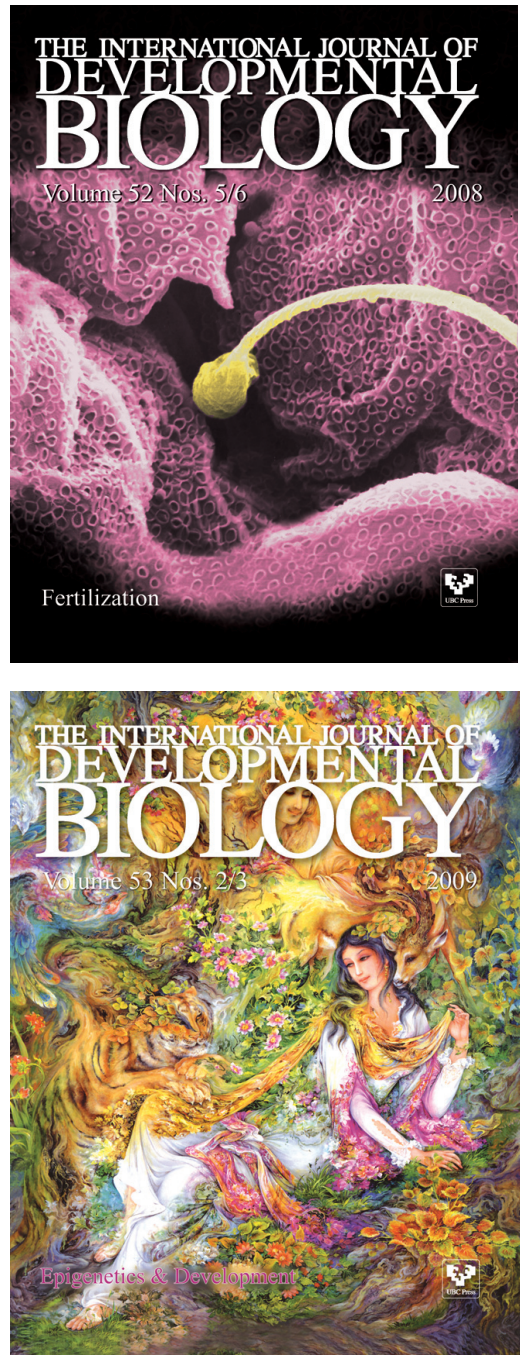

5 yr ISI Impact Factor $(2008)=3.271$

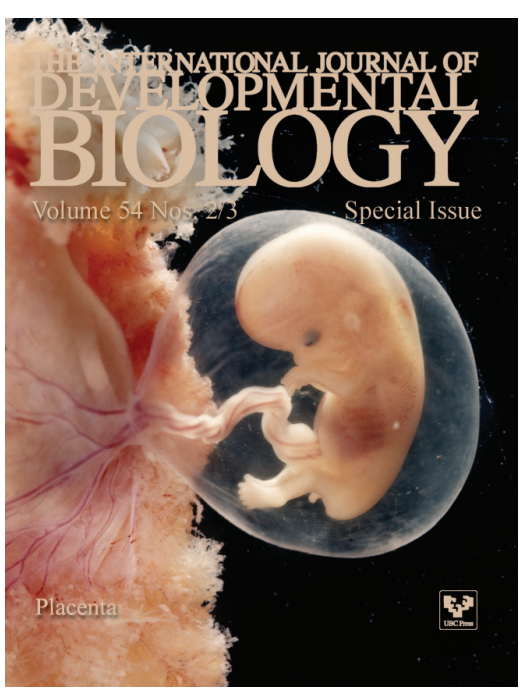

